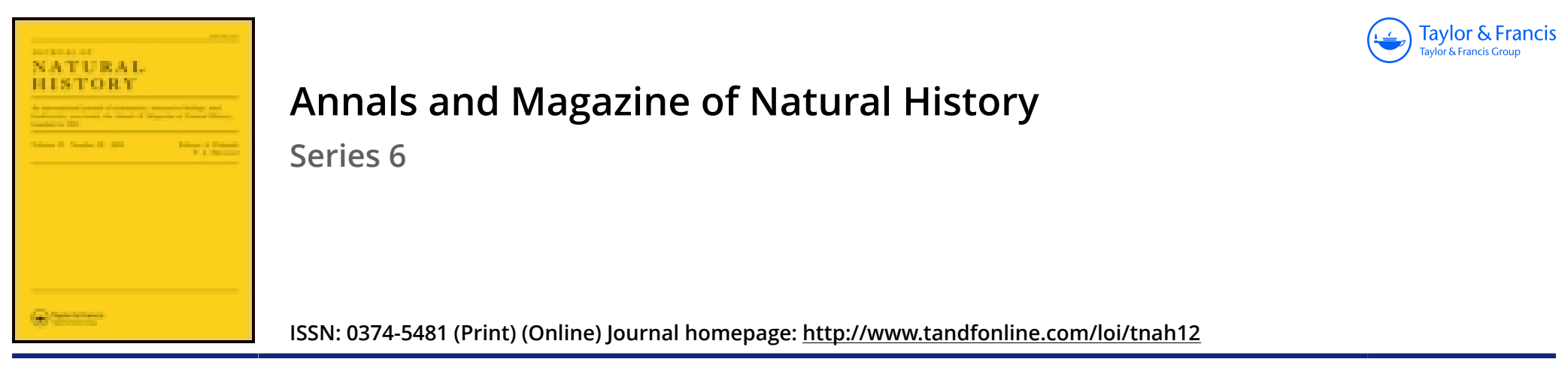

\title{
LXIII.-A month on the Trondhjem fiord
}

\author{
Rev. Canon Norman M.A. D.C.L. F.R.S.
}

To cite this article: Rev. Canon Norman M.A. D.C.L. F.R.S. (1893) LXIII.-A month on the Trondhjem fiord, Annals and Magazine of Natural History, 12:72, 441-452, DOI: 10.1080/00222939308677650

To link to this article: http://dx.doi.org/10.1080/00222939308677650

\section{Published online: 06 Oct 2009.}

Submit your article to this journal

LII Article views: 4

Q View related articles $\sqsubset$ 
LXIII.-A Month on the Trondhjem Fiord. By the Rev. Canon Norman, M.A., D.C.L., F.R.S., \&e.

[Continued from p. 367.]

[Plate XIX.]

B R A C H I O P O D A.

1. Terebratulina caput-serpentis, Linn.

Trondhjem.

Var. septentrionalis, Couthouy.

Rödberg, on the precipices. I have always regarded, and must still regard, this as only a variety of $T$. caput-serpentis, notwithstanding the opposite opinion held by G. O. Sars *, Davidsont, and Fischer and Ellert $\neq$. Sars thought he had found a permanent difference in the structure of the loop; but that has been proved not to be the case; the later authors rely on trifling differences, and I cammot find anything, either by the comparison of the hundreds of specimens which have passed through my hands or in the descriptions given, on which to found a valid species; the more specimens are examined the weaker is the evidence of real distinction, and T. caput-serpentis, var. germana, F. \& E., is a mere link in a chain. Davidson quotes in the memoir referred to, without apparently the least suspicion that anything was wrong, these words from Binney's edition of Gould's 'Report Invert. Massachusetts':- "The downy epidermis is a character too rare and too singular to be overlooked. 'This, however, is rubbed off very easily." In his description of the species also Gould had written:- " The whole [i.e. shell] covered by a thin, silvery, fibrous epidermis ;" and, again, "Deshayes conjectures, probably with justice, that

* G. O. Sars, 'Mollusca reg. aret. Norwegir,' 1878, p. 10.

+ Davidson, "Mon. Recent Brachiopoda," Trans. Linn. Soc. ser. 2, vol. iv. $(1880$ ) , p. 28.

† Fischer and Chlert, Exped. Sci. 'Travailleur' et 'Talisman,' Brachiopodes, 1891, p. 29; and Result des Campag. Sci. Prince Monaco, fasc. iii., Brachinpodes de l'Atlan. Nord, 1892, p. 9. 
the Anomia puhescens of Gmelin is the same thing." If we turn to Gmelin, Linn. Syst. Nat., edit. xiii., we find that the name Anomia pubescens is given to a shell on which Müller (Zool. Dan. Prod. 1776, no. 3007) thus writes:-_" Terebratula pubescens testa tomentosa, subquadrangulari, longitudinaliter striata, tomentum non omnes æqualiter vestit, spongiamque parasiticam suspicor ;" and Gmelin's own observations are "testa pilis brevissimis erectis distantibus, an forsan a Spongiæ specie adherente? hirta." The suggestion of these two old writers was the true one, while modern writers like Gould and Davidson have mistaken this hispid coating of sponge for an epidermis! But it must not be supposed that the hispid coating is due to one particular species of sponge. Two such are described by Bowerbank-Microciona lcevis, Bow. (Brit. Spong. vol. iii. pl. xxiii. figs. 7-11), and Halichondria albula, Bow. (vol. iii. pl. xlv, figs. 21-24). I have now taken three specimens at random procured at Rödberg and examined the hispid covering; all looked alike to the naked eye, but each shell had on it a spnnge not only specifically but generically distinct from the others, and none of them belonging to either of the species found on Terebratulina by Bowerbank*. Fischer and Ehlert give the same solution of the "epidermis," having found an incrusting sponge on their specimens which is yet another species, $S u b$ erites capillitium, Topsent. It would seem that the slightly roughened shell, combined probably with the advantage afforded in the way of nutriment brought by the currents of water which the Brachiopods set in motion, serve to make Terebratulina a friend highly esteemed among the Spongozoa.

\section{Waldheimia septigera, Lovén.}

This fine species is not rare at some spots near Rödberg; but I only myself found one living specimen on the precipices on the west side of the fiord at a great depth, probably 300 fathoms. I have also dredged it at a nearly similar depth off Batalden, near Florö. The Rödberg specimens are, however, larger than any I have seen from other places,

* One of the three is Myxilla ambigua, Bow. (= Microciona ambigua, Bow.). This is Hastatus ambiguus, Fristedt, who also found it incrusting Terebratulina. 
whether taken by myself or by the 'Porcupine' Expedition of 1869. The example procured is a narrow and very tumid form, measuring $1 \frac{1}{2}$ inch long, $1 \frac{1}{5}$ inch broad, and 1 inch deep; but, if my memory deceives me not, I saw larger specimens than this in the Trondhjem Museum, and fully the size of Davidson's measurement of his largest specimen. Fischer and Ehlert have figured on pl. iv. of the 'Travailleur' Report a very remarkable triangular form of this species, with almost straightly sloping sides and straight anterior margin, where it is of great breadth. Indeed, judging from the figures I should have thought that the form might possibly be referable to $W$. floridana, Pourtales, rather than to $W$. septigera.

\section{Waldheimia cranium, Müller.}

From 70 fathoms downwards, Trondhjem and Rödberg. This species I find generally distributed in the West Norway fiords, and I have also taken it in Lang Fiord, Sydvaranger, close upon the borders of Russia.

\section{Crania anomala, Müller.}

In 40-250 fathoms. Specimens from the precipices are large.

\section{T U N I C A T A.}

As there were several Tunicata which I was unable to determine I sent the animals of this class to Professor Herdman, who bas kindly examined them and sent the following notes. They will be more fully treated of in a paper which Professor Herdman has in preparation on the Tunicata of Norway.

\section{“A SCIDI A SIMPLICES.}

\section{"Fam. I. Molgulidæ.}

\section{"1. Molgula eugyroides, Traustedt*.}

"Three specimens from Rödberg, 250-300 fathoms. These agree so well with Traustedt's description and figures that I cannot separate them, although $M$. eugyroides has only been found previously off Bahia, South Atlantic.

" "Vestindiske Ascidix simplices," Vidensk. Meddel, fra den Naturh. Foren. i Kjöbenhavn, 1882, p. 37, pl. v. figs. 1-3. 


\section{"Fam. II. Cynthiadæ. \\ "Subfam. Streline.}

"2. Polycarpa pomaria, Sav. (?).

"About two dozen specimens from Rödberg, 150-250 fathoms, and several from Bergen Fiord (A. MI. N., 1878). These agree in almost all anatomical details with British specimens of $P$. pomaria, but the branchial sac has no intermediate horizontal membrane across the meshes. However, I do not lay great stress upon this, and I feel pretty sure that the specimens belong to Polycarpa pomaria.

“3. Polycarpa pusilla, Herdman *.

"Four specimens from Rödberg, 250-300 fathoms, and one specimen (in regard to which I am still a little in doubt) from Trondhjem, shallow water. This species was only previously known from the North Atlantic, 40 miles off Valentia, Ireland, 110 fathoms.

\section{"Fam. III. Ascidiidæ.}

"4. Ascidia compressa, O. F. Müll.

"Three specimens from Trondhjem, 20 fathoms, and Rödberg, 40-70 fathoms, and one from Rödberg, 20-40 fathoms. These are all rather small, an inch to an inch and a half in length, but agree well with large specimens from the north of Norway. They have the pharyngo-cloacal slit in the branchial sac like that of $A$. mentula. I am inclined to think that the $A$. obliqua of Alder may be this species, and A. falcigera, Herdman, from off Nova Scotia is at least very closely related.

"5. Ascidia plebeia, Alder.

"Two specimens, about half' an inch long, from Trondhjem, shallow water. Also two smaller specimens, in regard to which I have some doubt, from Rödberg, 100-200 fathoms. There are also a few other small Ascidians, which I consider too young to identify with certainty.

"6. Ascidiella venosa, O. F. Müll.

"Trondhjem, shallow water.

* " Report Tunicata 'Lightningr' and 'Porcupine' Expeds.," Trans. Roy. Soc. Edin. vol. xxxii. 1884, p. 224, pl. xxxv. figs. 4-6. 
"7. Ascidiella, sp.

"One specimen from Rödberg, 150-200 fathoms, is possibly a new species characterized by its very large stigmata, of which there are only two in each mesh, and by the very slender bar of the branchial sac.

" 8. Ciona intestinalis, Linn.

"Trondhjem, 20-10 fathoms, under western shore.

“9. Corella parallelogramma, O. F. Müll.

"One from Trondhjem, near Munkholmen, 20-40 fathoms.

“A SCIDI COMPOSIT.

"Fam. Didemniidæ.

"10. Leptoclinum tenue, Herdman *.

"Rödberg. This species was previously known from the coast of South America and from the Faroe Channel.

\section{"Fam. Polyclinidæ.}

"11. Amaroucium pomum, M. Sars (?) †. "From Rödberg.

[Note by A. M. N.-Two specimens growing side by side dredged in shallow water, each thus far agreeing with Sars's description :- " Polyparium magnitudine pugni, luteo-cinereum, subcartilagineum, globosum, absque pedicello, papillis parum eminentibus obtectum. Animalia flava (straminea)." From a memory of this description, at the moment when I dredged them, it flashed into my mind that these fine large compound Ascidians were Sars's species; but further than that I cannot say, as I did not dissect out the animals before, sending them to Professor Herdman.]

\section{"12. Psammaplidium, sp. n.}

" From Rödberg. All the species of this genus previously

* Report 'Challenger' Tunicata, pt. ii., Ascidire Compositie, 1886, p. 281, pl. xxxix. figs. $8-11$, pl. xl. fig's. 3-5.

$\dagger$ Beret. Somm. 1849 foretrgen Zool. Reise i Lofoten og Finmarken (Nyt Mag. for Naturvid. vol. vi., 1851), p. 35. 
known are from the Antarctic, the South Atlantic, or the Australian Seas.

"13. Aplidium, sp.

"Several small colonies, which cannot be identified with any certainty."

\section{POLYZOA.}

Having during previous dredgings in Norway paid much attention to the Polyzoa, I had a large mass of material, examined and unexamined, belonging to this Class from the fiords. I did not therefore, on the present occasion, search for incrusting species, but gave the time thus saved to other things. The few incrusting forms in the following list were accidentally noticed, but it will be seen that the arborescent Polyzoa are of great interest.

\section{Menipea Jeffreysï, Norman. (Pl. XIX. fig. 1.)}

1868. Menipea Jeffreysii, Norman, "Notes on some rare British Polyzoa, with Descriptions of new Species," Quart. Journ. Micr. Sci. n. s., vol. viii. p. 213 , pl. v. figs, $4-8$.

1880. Menipea Jeffreysiz, Hincks, Brit. Marine Polyzoa, p. 42, pl. ix. figs. 1,2 .

Menipea Jeffreysii was described from two very minute fragments, each about 2 millim. long, which were picked out by the late Mr. C. Peach from shell-sand dredged by Jeffireys and myself off Shetland and in the Minch. 'I'he description of these worn fragments was therefore imperfect, and I will now give full details of this very distinct species.

Zoarium very transparent and glassy, arising from a single stem composed of a coil of chitinous tubes, and attached by the base usually to a small pebble or fragment of shell, dichotomously branching, branches all in one plane. Zoccia 6 to 9 and sometimes more in each internode, aperture regularly elliptical, occupying half the length of zoccium; in young cells armed in front with three long spines, the innermost much more slender than the others, but in older zocecia this innermost slender spine has generally been broken off at the base and is no longer perceptible, while the others remain as short, more or less stumpy spines; fornix (operculum) attached near the upper end of the inner margin, very large, convex, cap-like, and so closely fitted down to the aperture that, viewed from above, it appears to be part of the cell, and only careful lateral inspection shows the narrow open line 
Anru.\& Mag. Nat. Hist. S. 6. Vol. XII. Pl. XIX.
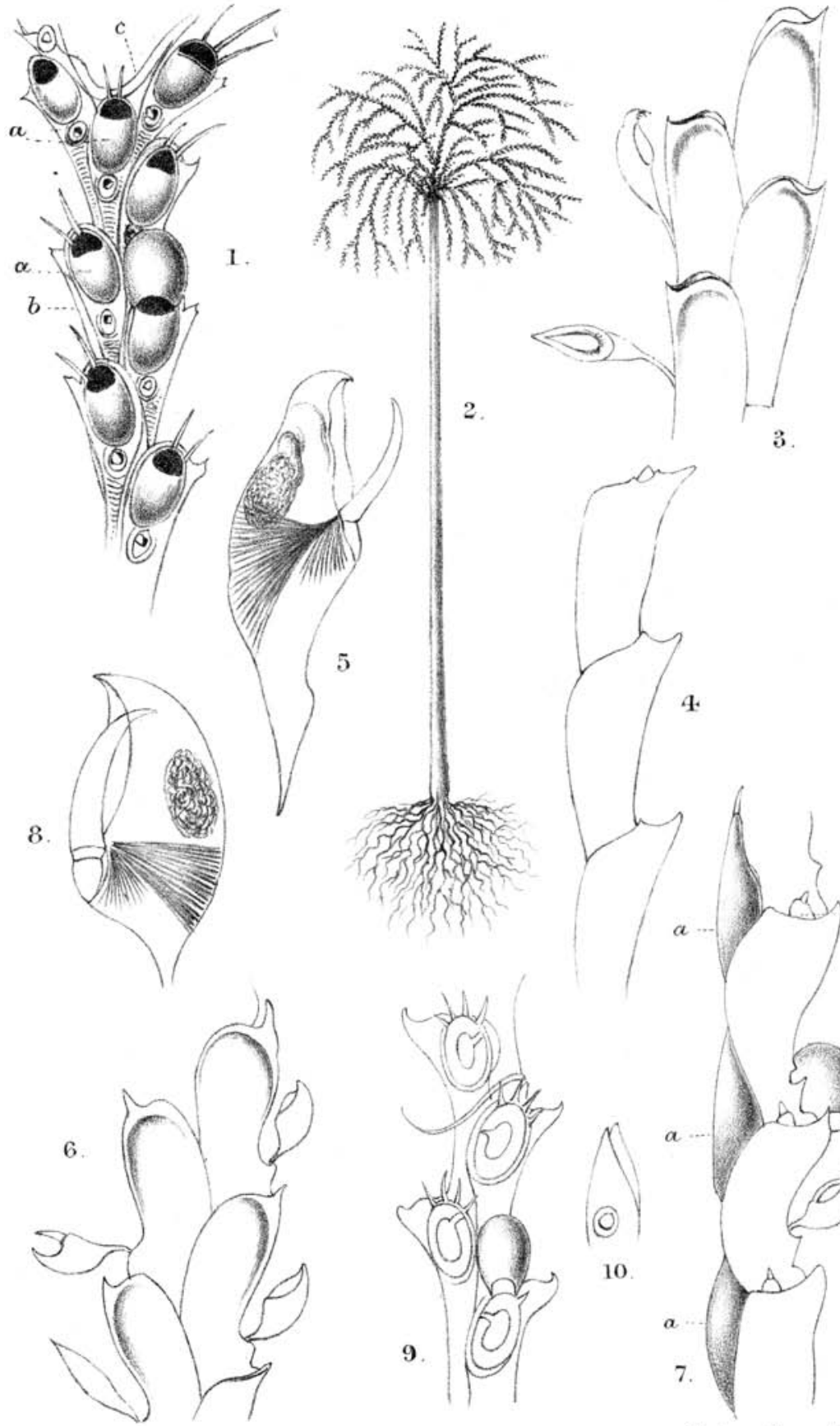

5

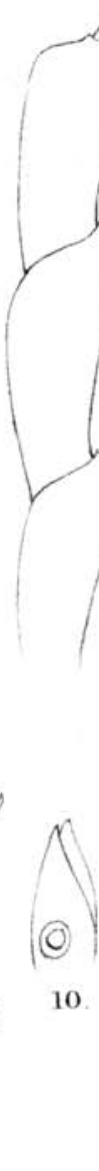

3.

A.M.N. del.
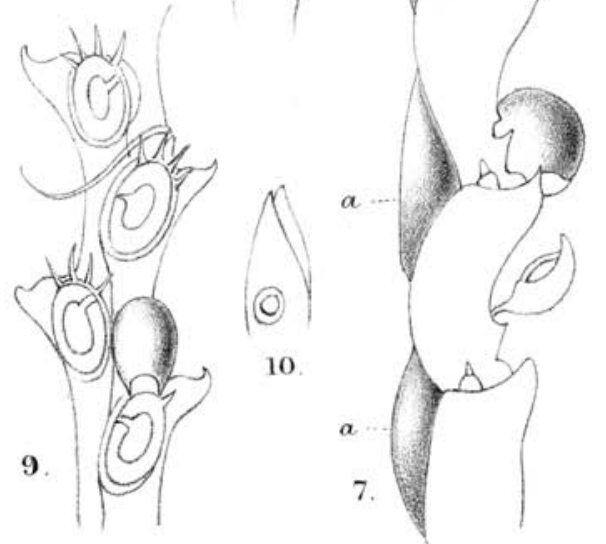

Minterm Bros . Jith. 
which marks its separation from the mouth-margin; the illusion is heightened by the fact that the anterior edge of the operculum is projected at a right angle across the mouth, leaving in front an opening exactly semicircular in form. The whole cell thus mimies the appearance of a Lepralian. 'Two avicularia on each cell-one central, raised, situated a little behind the aperture; the other lateral, in the usual position, very small, the outer margin of the cell embracing it from below without any angularity. The occium is rather longer than wide, not globose, but depressed slightly above, inclining inwards.

But a most marked peculiarity of this Menipea is seen at the back of the zoarium, which is overlaid throughout from the base to the most recently developed cells by chitinous tubes; these tubes, where not so numerous, generally wind in and out among the cells, but on the lower part, where they are more numerous, they completely cover the whole back; moreover, one of these tubes generally (if not always) passes round the base of each bifurcation (see Quart. Journ. fig. 6, and here, Pl. XIX. tig. 1, c), as though to give strength to that part; sometimes also one of the tubes runs along the edge of each side of the zoarium, so that, when viewed from above, there is seen a transparent margin (Pl. XIX. fig. $1, b$ ) extended outside the cells. Height of my tallest specimen 32 millim. (not quite $1 \frac{1}{2}$ inch).

Rödberg, Trondhjem Fiord, 150 fath.; also Kors Fiord, 180 fath. ; Hardanger Fiord, 150-180 fath. ; Florö, 35 fath.; and Bog Fiord, East Finmark, 150 fath.

Specimens from all these localities agree in every particular. They are at once distinguished from all other species of the genus by the peculiar dorsal overlying of chitinous tubes and the large close-fitting cap-formed fornix, as well as by the presence of the central and the small size of the lateral avicularia.

The description and figure here of this species are so different from those previously given that some explanation is recessary. Alder's figure illustrating my paper (pl. v. fig. 8) and Hincks's figure (pl. ix. fig. 1) were both taken from the same specimen; the former incorrectly thought that the broken remains on the upper occium-bearing cell represented a branched fornix. This error I corrected in my description, and Hincks drew it as entire, adding two similar fornices to two other cells where they were not actually present in the specimen. I mention this trifle because the curious circumstance is this, that all the time there was a perfect fornix on the lowest zoccium of the right-hand 
side, which we none of us recognized as such, its character being so entirely different from any previously known form of that organ. Alder represented on fig. 6 certain organs on the back of these zoceia, which apparently I could not see, as I did not describe them. These, I take it, were the central avicularia appearing through by transmitted light, and their position rather altered by refraction. Lastly, the very small imperfect lateral avicularia, which I had mistaken for broken spines, Hincks rightly recognized as avicularia.

\section{Kinekoskias Smitti, Danielssen. (Pl. XIX. figs. 2-5.)}

1867. Kinekoskias Smitti, Danielssen, Fürhandl. Vidensk.-Selsk. Christiania, 1867 , p. 23 (quoted from Ian. \& Kor.).

1868. Bugula Smitti (Kinekostias, Dan.), M. Sars, Forsatte Bemærk. over dyriske Lirs Udbred. i Havets Dybder (Vidensk.-Selsk. Förhand. 1868), p. 255 (name only).

1877. Kinekoskics Smitti, Dan. \& Koren, Fauna Littor. Norvegire,

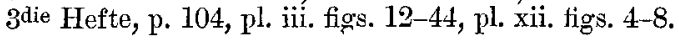

I had the satisfaction of procuring several perfect examples of this rare and remarkable Polyzoon in about 70 fathoms at Rödberg. I was previously indebted to Dr. Danielssen for the head of a specimen of the species he had described, but had not seen the perfect form until I went to Trondhjem.

Other known localities for this species are Stotholmen Fiord, Nordland, 80 fathoms (Danielssen), Kors Fiord, entrance to Bergen Fiord, 150-200 fathoms (Danielssen and Koren), 300 fathoms, no locality (M. Sars).

Among the Polyzoa of the 'Challenger' Expedition two species attracted great attention-Cephalodiscus dodecalophus, M'Intosh, and one which Wyville-Thomson described as Naresia cyathus, and which Busk afterwards found to be so closely allied to Kinekoskias Smitti that he had some doubt whether it was distinct or not. It will be well therefore to clear up this matter, and $I$ am indebted to the British Museum for a small fragment of the type of Thomson's species which enables me to make direct comparison. I shall take it for granted that the descriptions already given of the two species have been consulted, and shall only draw attention to points of difference or corrections of errors.

\section{A. Kinekoskias Smitti, Dan. (Pl. XIX. figs. 2-5.)}

The total height is $4 \frac{1}{2}$ inches; of this the first three quarters of an inch is composed of the dense mass of fine rootlets which are distributed through the mud and hold the zoarium in its position; the next three inches are the stem, which is about 
2 millim in diameter at the base, and thence tapars gently to the summit, where it is half that diameter. When living the stem is cylindrical and vertical, so that the crown of branches is held at its height above the mud; but when dead all efforts to preserve it in its natural form failed and the sides entirely collapsed, and it is thus evident that the stem is composed of a very delicate smooth surrounding membrane, filled with fluid; the fluid must escape, I think, at the top of the stem between the bases of the branches, as I cannot find any rupture in the side-walls. Delicate as the membrane which forms the stem is, it is of considerable strength; the stem may be bent in any number of folds, it will not break. At the summit of the stem this membrane expands and invests the base of the crown, extending a little distance up the branches, on the sides of which it is extended as a thin film. The crown is about $\frac{3}{4}$ inch high, and is composed of dichotomously dividing flexible branches.

The zocecia viewed from above (Pl. XIX. fig. 3) have the lateral margin straight, without any sinus, and the terminal spine-point is small and does not rise above the slightly projected anterior margin of the zoocium ; viewed laterally (fig. 4) the dorsal margin is seen to be straight or only very slightly arcuate. The avicularia (fig. 5) are greatly elongated and at the base the point of attachment is extremely fine; they spring from the delicate lateral margin of the zoceium about or a little above the middle, and are so long that they project when directed forwards considerably beyond the summit of the zoocium, sometimes by the whole length of the mandible.

\section{B. Kinekoskias cyathus (Wyville-Thomson). (PI. XIX. figs. 6-8.)}

1877. Naresia cyathus, Voyage of the 'Challenger,' The Atlantic, p. 142 , and woodcut.

1881. Bugula (Kinekoskias) cyathus, Busk, Quart. Journ. Micr. Sci. n. s. vol. xxi. p. 1 , pl. i. figs. $1,3,4$.

1884. Kinekoskias cyathus, Busk, Report 'Challenger' Polyzoa, The Cheilostomata, p. 44, pl. viii. figs. 1 and $1 a-c$.

Judging from the figures given, as well as from the fragment which I have had the opportunity of examining, this species is much less flexible and more charged with calcareous matter than the last. Hence its crown, which is also considerably larger than that of $K$. Smitti in relation to the height of the stem, stands up more stiffly. But be that as it may, the following points afford good specific characters.

The zocecium seen from above (Pl. XIX. fig. 6) has the outer margin flexuous; at a short distance from the base it suddenly Ann. \& Mag. N. Hist. Ser. 6. Vol. xii. 
falls back, forming here, as Busk says, "a sort of step;" from this point it arches very gently forward, terminating in a spinepoint; this spine-point is rather larger than in the last species and extends beyond the anterior margin of the zocecium; viewed laterally (fig. 8) it is seen that the back of the zoccium is very convex, the form being spoon-shaped and reminding one of that of the cell in Mollia patellaria, Moll*. The avicularium (fig. 7) is much shorter and stouter than in the last species, and is attached behind the middle of the zoncium to the "step" described; when directed forwards it does not nearly reach the end of the lateral margin.

Thus both in form of zoccium and avicularium this species is quite distinct from $K$. Smitti.

'The figures of the avicularia in the 'Challenger' Report are very inexact. They are represented as mounted on a pedicel, and in some instances an articulation is drawn at the summit of the pedicel. There is nothing of this. The avicularium itself tapers downwards to a very small point, which point is the attachment to the zocecium.

I do not see in my specimens of $K$. Smitti that the "lower narrower part of the posterior surface" is "transversely striated," as described by Danielssen and Koren, and referred to by Busk as perhaps of specific importance to distinguish that species from $K$. cyathus.

An interesting point in Kinekoskias is the development of the mass of root-tibres by which the species anchor themselves in the mud. Observations on this subject will be found in Busk's paper in Quart. Journ. Micr. Sci. I do not remember any other Polyzoa which have rootlets of this character, though different species have very varied modes of attachment. But it is an interesting fact that among many classes of mudinhabiting animals similar modes of anchoring are found. The throwing out of a bundle of fibrous processes which, permeating through the fine mud in all directions, act in the way of roots to support the animal in an upright position, oceurs not only in Kinekoskias among the Polyzoa, but also among the Echinodermata in Rhizocrinus lofotensis, M. Sars, among the Hydrozoa in Aglaophenia radicellata, G. O. Sars, and among the Spongozoa in many species, preeminently in Stylocordyla borealis, Lovén, and s'. stipitata, Carter.

* Why is Diachoris, Busk, 1851, used for this genus instead of Mollia, Lamouroux, 1816? The fact that the name has been misapplied by some authors is no reason why it should not be rightly used, and Eschara patellaria, Moll, is the type of Lamouroux's genus. 
3. Scrupocellaria intermedia, sp. n. (Pl. XIX. figs. 9, 10.)

Rödberg, on the precipices.

I cannot assign this form satisfactorily to any known species. It comes nearest to $S$. scrupea, a southern form not yet known north of the south of England. With that species it agrees in the form of the fornix, of the lateral avicularia, and of the vibracular cells, which latter are present on every zoccium, and in the absence of an avicularium on the front of the cell. It differs in its more slender habit and more elongated cells (in $S$. scrupea the mouth-openings overlap each other, here they are quite distinet), and in the occium, which in S. scrupea is wider than high and very convex, here is somewhat loop-formed, being narrower at the mouth than a little above it, much longer than wide, and flattened centrally ; there are four spines at the summit of the cell. In habit this species approaches more nearly to $S$. scruposa, from which it is distinguished by the presence of a fornix. From the northern $S$. scabra it differs in the absence of an avicularium on the front of the zonecium and the entirely different form of the vibracular cell *.

4. Caberea Ellisii, Fleming.

Rödberg and Trondhjem, frequent.

5. Bicellaria Alderi, Busk, =B. unispina, M. Sars. Trondhjem, 150 fath.; Rödberg.

6. Flustra Barleei, Busk.

Not uncommon on the precipices. Here, and in all other West-Norway fiords where i have taken the species, the habit of the species is different from that of specimens from the sea round Shetland. For the form of the latter see Hincks, pl. v. fig. 6 , which was drawn by Mr. Alder from a specimen in my collection. In Norway, on the other hand, the zoarium generally assnmes the form of long narrow strips. Flustra Barleei is common in the West-Norway fiords. It

* I take this opportunity of dissenting from Mr. Hincks's view that my S. inermis is the same as the Miocene fossil S. elliptica, Reuss; one of that author's tigures shows three spines on the front margin of the cells, and the dorsal view looks quite different, representing the zocecia as very tumid in that part. Many of Reuss's species described in this and other papers may prove to be recent; but it is difficult, except in the case of very marked forms, to judge, without comparison of specimens, of the identity of fossil with recent species, especially in such a genus as Scrupocellaria, where most of the organs in a fossil are in an imperfect state. 
is not referred to in Smitt's original work; but he subsequently recorded it from off the West-Finmark coast, and pointed out the differences between this species and his Flustra membranaceo-truncata. They may at once be separated by their avicularia, which in the former are nearly circular and are placed obliquely (vide Hincks, pl. v. fig. 7) and in the latter are oblong and are placed uprightly with respect to the zoarium (vide Smitt, pl. xx. figs. 2, 3). I have examined many specimens of Smitt's species, including a type received from the describer.

[To be continued.]

\section{EXPLANATION OF PLATE XIX.}

Fig. 1. Menipea Jeffreysii, Norman. $a$, the fornix; $b$, chitinons tube from the back, here running along the side of the zoarium; $c$, chitinous tube forming a loop uniting the divaricating branches.

Fig. 2. Kinekoskias Smitti, Danielssen, nat. size.

Fig. 3. Ditto. Zoocia seen from the frunt.

Fig. 4. Ditto. Zooecia seen from the side.

Fig. 5. Ditto. Avicularium.

Fig. 6. Kinekoskias cyathus (Wyville-Thomson). Zoøein viewed from the front; part of the type 'Challenger' specimen.

Fig. 7. Ditto. Zooecia viewed from the side, $a$, back of the further row of zooecia appearing in the hollows of the zoocia of the nearer row; $b$, an organ I do not feel sure about, possibly the point to which the muscles of the animal are attached, but I cannot see any muscles thus attached.

Fig. 8. Ditto. The avicularium.

Fig. 9. Scrupocellaria intermedia, Norman. Front view of zocecia.

Fig. 10. Ditto. One of the upright vibraculum cells from the back of the zoocium, more enlarged than fig. 9.

\section{LXIV.-On some new or little-known Species of Coleoptera from the East. By the Hon. WaLter Rothschild and Dr. K. JORDAN.}

\section{Theodosia Howittii (Cast.).}

Among some specimens of this fine species recently received from Kina Balu, North Borneo, is a large male, measuring 52 millim. from the tip of the prothoracic horn to the apex of the abdomen; the horn on the head is more than 30 millim. long. Both horns are deep coppery, tinged with purple. 